\title{
Optimizing Household Economic Resource to Lessen Population Pressures on Villages around Kerinci Seblat National Park Bengkulu Province
}

\author{
Ketut Sukiyono", Septri Widiono \\ Department of Agricultural Socio-Economics, Faculty of Agriculture University of Bengkulu \\ Jl. W. R. Supratman, Kandang Limun, Muara Bangka Hulu, Bengkulu, Indonesia 38371
}

Received May 28, 2020/Accepted November 18, 2020

\begin{abstract}
Villages around Kerinci Seblat National Park (Taman Nasional Kerinci Seblat, TNKS) have experienced population pressure. This condition which if not addressed immediately will encourage the community around the TNKS to enter and encroach the forest to meet their household needs. This is getting worse along with the finding that the community around TNKS also does not have many alternative sources of income. For this reason, designing strategies for optimizing household economic to lessen population pressures are noteworthy. Focus group discussion (FGD) and analysis hierarchy process (AHP) was applied to design and to determine development strategy for household economic empowerment and twenty-five key informants including fifteen farmer households were interviewed. The AHP results conclude that the production aspect is the most important that needs to be given priority in the development of plantation production. This conclusion is based on its highest relative priorities (weights), i.e., 0.298. Of the three programs identified and using weight result of AHP, community seed assistance is the most important program in the development of plantation production (weight of 0.494). The seed assistance program is the most important compared to providing soft loans (weight of 0.29) and expanding to production inputs accessibility (weight of 0.216). Meanwhile, human resource development aspects are the most attractive strategy for food crop production development, especially rice, with a weight of 0.325. Aspects of human resource development are more focused on improving farmer knowledge in cultivation than marketing and post-harvest handling aspects. Optimization of pekarangan resources is directed to the development of the chicken farm (weight $=0.274)$ focused on improving the production aspect (weight $=0.328)$. Among three priority programs, day-old chicken assistance $($ weight $=0.512)$ is more needed than access to soft loans (weight $=0.242)$ and feed programs $($ weight $=0.246)$.
\end{abstract}

Keywords: economic empowering, AHP, TNKS, population pressure

*Correspondence author, email:ksukiyono@unib.ac.id

\section{Introduction}

Kerinci Seblat National Park (Taman Nasional Kerinci Seblat, TNKS) is Sumatera's largest national park covered an area of $13,750 \mathrm{~km}^{2}$. This national park area is administratively situated in 4 provinces, namely West Sumatera, Jambi, Bengkulu, and South Sumatera. Bengkulu Province covers an area of 310,579 ha or approximately $21 \%$ of the total TNKS area which includes North Bengkulu and Rejang Lebong districts with 34 villages around the TNKS. Several reports indicate that TNKS is facing a chronic encroachment problem. In Bengkulu Province, for instance, Rambe (2012) reports that the area of the TNKS that has been encroached is up to 6,470 ha. Earlier, WALHI Bengkulu (2008) has reported that $36.27 \%$ of the 340,575 ha area covered by the Bengkulu Province administrative area had been severely damaged (non-forest condition). There are assertions that the community has gradually converted this forest into various other forms of land use, such as settlements and yards, farming, estates and plantations, and so forth. The encroachment of protected forests was determined by the economic pressures of the communities around the protected forests as reported by Subarna (2011).
Research on TNKS also found that villages around TNKS generally have been under pressure as concluded by Widiono et al. (2013). This conclusion is based on a higher value of the population pressure index. Widiono et al. (2013) also inform that 18 of 20 villages around TNKS studied have experienced overpopulation. The population pressure index is formed by several important components, especially the population growth rate, land productivity, and the proportion of off-farm income. In addition, research by Sukiyono et al. (2015) conclude that households in the villages around Kerinci Seblat National Park (TNKS) Bengkulu province mostly relied solely on one type of work, especially the agricultural sector. By relying only on the agricultural sector as the main source of income, households tend to be vulnerable if there is a change in the agricultural sector, especially plantation sectors such as coffee and rubber which are mostly cultivated by farm households around TNKS. Less diverse sources of income are also identified by Windirah et al. (2014) and Sukiyono et al. (2013). Using Income Diversification Index (IDI), they found that the source of income households is limited and the contribution of each income source is uneven as indicated by the low 
value of IDI. The low value of IDI indicates that households depend only on one or two types of income to support family members and themselves. Sukiyono et al. (2013) also informs that only $37 \%$ of the population have two income sources and eight percent have three income sources.

Generally, multi income strategy by diversifying income sources is an alternative solution to lessen population pressures. In addition, research by Misra et al. (2014) conclude that forest resource density can be maintained at an equilibrium level by controlling population pressure by providing economic incentives. Development of nonfarm activity or income diversifying is considered to enlarge the carrying capacity of the land externally and to improve the proportion of off-farm income. Many studies conclude that income diversification has an important impact on income, income distribution, and welfare across rural households (Reardon et al., 2000; Block \& Webb, 2001; Canagarajah et al., 2001; Rachman et al., 2006). Income diversification is also a strategy to cope with livelihood risks (Barrett et al. 2001; Guvele, 2001; Démurger et al., 2010). In the case of Africa, a study by Bryceson and Jamal (1997), Reardon (1997), and Little et al. (2001) find that nonfarm income sources may already contribute as much as $40-45 \%$ of average household income and tend to be growing in importance. Income diversification in rural China, as reported by Wan et al. (2016), could help rural households to reduce the adverse impact of drought, enhance their resistance and resilience to drought, and make their livelihood system more stable.

However, the problem is that not all households have access, due to relatively limited employment access or because of the necessary conditions, such as education and skill, to diversify their incomes. The lack of employment available and accessible to households is also indicated by a low level of the economic diversification index (IDI) in every single village around TNKS as revealed by Sukiyono et al. (2013) research. They concluded that the limited physical, capital, and skill proficiency of every household member become a constraint for developing secondary and tertiary sectors in that area to diversify their income. These findings were similar to Barrett et al. (2001) and Losch et al. (2011). Therefore, the best strategy is to increase the carrying capacity of the environment by optimizing household economic resources. Another option is the intensification of agriculture by increasing the use of modern agricultural technology. The goal is to improve the productivity of agricultural land. If land productivity is improved, then it can reduce the population pressure. This means that the carrying capacity of the environment will increase. But that does not mean that other efforts are not needed as suggested by Weinberger and Lumpkin (2007), which is to take advantage of market opportunities and agricultural products that have high economic value and research advice from Huang et al. (2009) by utilizing employment opportunities outside agriculture. However, optimizing the economic resources owned by every household becomes a very relevant option. One of the important reasons is that these economic resources are already owned by households and have not been used optimally, especially the yard of an average of $1,302.57 \mathrm{~m}^{2}$ household $^{-1}$ (Sukiyono et al., 2013). Furthermore, the importance of optimizing household economic resources is also based on the significant contribution of forest products, both timber and non-timber, to the household economy. Forest products that were mostly used were firewood, hunting animals, and building timber, each with $33.33 \%$; $26.67 \%$, and $2.50 \%$ respectively (Sukiyono et al., 2014). Despite the relatively small building-timber taking it indicates they do illegal logging. Research by Sukiyono et al. (2014) also found that the contribution of forest product income, both timber and non-timber, reached approximately $8 \%$ of total household income per month. Even though the contribution is relatively small, if this condition is not handled, the possibility of households encroaching on the forest will increase along with the increase in household needs. This is also based on the research findings of Sukiyono, et al. (2014) where on average households access the forest 2 times per week and they go with their village colleagues. Departing from the discussion of previous research findings, this study aims to design a strategy of community economic empowerment around TNKS to reduce the population pressure which in turn will be able to preserve the forest resources.

\section{Methods}

This research was conducted in villages in Lebong Regency which is located around TNKS. The research location was chosen purposively by selecting 3 sub-districts and from each sub-district, the village closest to the TNKS area was selected. The three selected sub-districts consist of Rimbo Pengadang, Bingin Kuning, and Pinang Belapis respectively while the selected villages involve Tambang Sawah, Talang Leak, and Talang Ratu.

The household economic development strategy is formulated based on focus group discussion (FGD) results, interviews with key informants (key persons), and the results of analysis hierarchy process (AHP) analysis. The objectives, alternatives, and criteria for empowerment strategies used in FGD and AHP are formulated from presurvey results and discussions with key informants competent on community empowerment. This means that this research was conducted into two stages. The first stage was collecting and identifying information related to households' economic activities that should be developed and require to improve. This stage is also intended to explore the criteria used to select household economic activities to be developed. This activity was conducted through a FGD involving academicians, researchers, regional planners, and successful farmers. The second stage was an interview with key persons to select a strategy to develop household economies by using a structured questionnaire-based study.

Key informants in research are people who can provide information about the situation and conditions of the research setting. Key informants determined by purposive sampling technique, namely, the sampling technique is based on certain objectives (Sukiyono, 2018) and selected who have the criteria as a sample. Key informants are those who know the conditions in accordance with the phenomena and economic conditions of the villages around TNKS and its development. Interviews involve 25 key persons from several agencies related to the economic development of the 
community, namely the Regional Development Planning Board (BAPPEDA) of Lebong Regency, the Lebong District Agriculture Office, the Lebong District Forest Service, the Animal Husbandry Department, the three sub-districts heads, involving the Rimbo, Bingin Kuning and Pinang Belapis Sub-district, and three village heads, namely, Tambang Sawah, Talang Leak and Talang Ratu Village, as well as 5 farmers from each village or a total of 15 farmers. Interview results are then analyzed by using AHP developed by Saaty (2008). AHP has been applied to various decisionmaking problems. Among others are Chang et al. (2007) in production, Timor and Tuzuner (2006) in the firms' sales representatives selection, Gnanasekaran et al. (2006) in the selection of supplier, and Al-Harbi (2001) in project management.

\section{Model development AHP for household resources optimizing strategy selection AHP techniques are used to identify and determine priorities in complex decision making. AHP is a decision-making method for choosing priority alternatives when many criteria are to be considered. Saaty (2008) noted that AHP is based on the well-defined mathematical structure of consistent matrices and their associated eigenvector's ability to generate true or approximate weights. This methodology compares criteria, or alternatives concerning a criterion, in a natural, pairwise mode. Detail explanation and discussion of AHP can be found in Saaty (2012) and Brunelli (2015).}

The following steps associated with the AHP method for decision making are as follows: first, to build a hierarchy for the decision, called decision modeling. This consists of the hierarchy of problem structures to be solved. The first level of the hierarchy was the objective of this research, selecting a strategy for improving the household economies. The second level was constituted by the criteria used to select strategy and the third level consist of the available alternative strategies. Figure 1 presents the general structure of the decision hierarchy for improving household economies.

The second step in the AHP method was to derive the relative priorities (weights) for the criteria. It should be noted that not all criteria are equally important in a given time. In other words, the importance or weight of each criterion will be different. By using a numerical scale for comparison developed by Saaty $(2008,2012)$, each criterion is compared to other criteria. Saaty $(2008,2012)$ adds that multiple pairwise comparisons of each criterion are based on a standardized comparison scale of nine levels and this comparison will result in a comparison matrix. By following closely notation suggested by Shahroodi et al. (2012), let $\mathrm{C}=$ $\{\mathrm{Cj} \mid \mathrm{j}=1,2, \ldots, \mathrm{n}\}$ be the set of criteria. The result of the evaluation matrix in which every element $a_{i j}(i, j=1,2, \ldots, n)$ is the quotient of weights of the criteria, as shown in Equation [1].

$$
A=\left[\begin{array}{cccc}
\alpha_{11} & \alpha_{12} & \cdots & \alpha_{1 n} \\
\alpha_{21} & \alpha_{22} & \cdots & \alpha_{2 n} \\
\vdots & \vdots & \ddots & \vdots \\
\alpha_{n 1} & \alpha_{n 2} & \cdots & \alpha_{n n}
\end{array}\right]=\alpha_{11}=1, \alpha_{j i}=\frac{1}{\alpha_{i j}}, \alpha_{i j} \neq 0
$$

The next step is to extract the relative importance implied by the previous comparisons, that is, how important are alternatives when they are considered in terms of the criterion used? This question can be answered by estimating eigenvector and eigenvalue as suggested by Saaty. The maximum eigenvaluemax $\lambda$ can be estimated as shown in Equation [2] (Shahroodi et al., 2012).

$$
\lambda_{\max }=\sum_{j=1}^{n} \alpha_{i j} W_{j} \frac{1}{W_{i}}
$$

note: $\lambda_{\max }$ is the maximum eigenvalue in the judgment matrix, $W_{j}$ and $W_{i}$ is the weight of $\mathrm{j}^{\text {th }}$ and $\mathrm{i}^{\text {th }}$ factor. If $\mathrm{A}$ represents consistency matrix, eigenvector $\mathrm{X}$ can be estimated as shown in Equation [3].

$$
\left(A-\lambda_{\max } I\right) X=0
$$

What distinguishes AHP from other decision-making models is the absence of absolute consistency. The AHP model uses the key informants' perception as its input hence inconsistency may occur because humans have limitations in expressing their perceptions consistently especially if they have to compare many criteria. Based on this condition, the decision-maker can express his perceptions freely without having to think whether the perception will be consistent or not. The consistency determination is based on the maximum eigenvalue. The obtained by the ormula as shown in Equation [4].

$$
C I=\frac{\lambda_{\max }-n}{n-1}
$$

note: $n$ is the matrix size or the number of items that are being compared in the matrix.

Based on Equation [3], the consistency ratio (CR) can be estimated as shown in Equation [5].

$$
C R=\frac{C I}{R I}=\frac{\frac{\lambda_{\max }-n}{n-1}}{R I}
$$

note: RI represents average consistency index over several random entries of same order reciprocal matrices. Saaty (1980) noted that CR is acceptable if it is not greater than 0.10 . If it is greater than 0.10 (or $10 \%$ ), the judgment matrix will be considered inconsistent. However, Byun (2001) suggests that 0.20 (or $20 \%$ ) might still be acceptable. To facilitate estimation, Expert Choice 11 version software is used in this study.

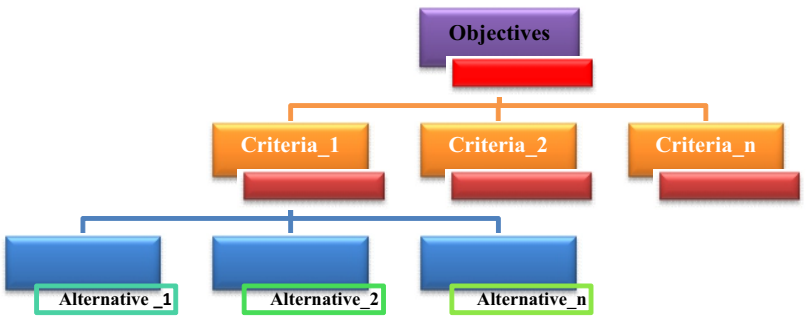

Figure 1 AHP structure. 


\section{Results and Discussion}

Result of focus group discussion (FGD) Forests are a natural and renewable resource provided a lavish in flora, fauna, and other environmental services. The diversity of forest abundance often becomes the source of the surrounding community in fulfilling their daily needs. Wollenberg. et al (2004) reported that based on CIFOR observations of an estimated 220 million population, 48.8 million of them live in state forest areas and around 10.2 million of them are considered poor. This means that the high dependence of local communities on forest products accompanied by high population growth causes forest resources to experience a continuous depletion in quality and quantity, as pointed out by Simon (2000), Dubey et al. (2009), Dubey and Narayanan (2010), and Dubey (2012). Accordingly, even though the contribution of forest products tends to decrease continuously (Sukiyono et al., 2014), efforts to reduce dependence on forest products are very important policies.

The question that arises is what policies or programs should be prioritized so that forest communities do not depend much on forests and their products. If the agricultural sector is a priority, many studies have concluded that people's dependence on the agricultural sector causes high population pressure (Senoaji \& Ridwan, 2006; Widiono et al., 2013). Thus, policies and programs should not be based solely on agriculture, but all development efforts are based on economic resources owned by households. In particular, the empowerment of household economic resources that have not been utilized optimally.

From the FGD, the household economic optimizing strategy is based on two properties. These involve the main crops cultivated by households, including plantation and food crops, and potential untapped economic resources owned by households. For plantation crops, farmers produce rubber, coffee, and or palm, while for food crops, farmers grow paddy. FGD results also conclude that there are 4 (four) main aspects that need to be developed, namely: aspects of production, marketing, human resources, and technology. Furthermore, two unexploited resources owned by households are home yard (pekarangan) and labor. Optimizing pekarangan by employing household labor is the best option for diversifying household income. FGDs also result in the conclusion that the commodities that should be developed in the pekarangan are livestock-based. The problem of which the livestock wants to be developed needs to be further explored based on four criteria, namely (a) the needs of the workforce, (b) capital requirements, (c) the amount of income, (d) the waiting period, (e) livestock raising, and (f) marketing. To answer all these questions and concerns, a quantitative approach by developing an AHP model will be used in this study. In summary, the objectives, criteria, and alternative strategies offered resulting from FGD are presented in Table 1.

Development plantation crops As mentioned above (Table 1), there are 4 aspects or criteria that seem to be the main concern, namely aspects of production, marketing, human resources, and technology. Each respondent has their views on each aspect of development. That is, each respondent has a different assessment of aspects of development, especially related to the most important aspects of development to be prioritized. Therefore, the AHP quantitative approach is used in this study. To increase the production of plantations, AHP produces priority development aspects as follows: (a) marketing with a weight of 0.216 ; (b) human resources with a weight of 0.235 ; (c) technology weighting 0.252 ; and (d) production with a weight of 0.298. AHP results also show that the inconsistency ratio is 0.02 . This figure indicates that the answer given by key informants is quite consistent because of the magnitude of the inconsistency of only $2 \%$. Saaty (1990) says that in AHP, matched comparisons presented in the matrix are considered consistent when the consistency ratio is less than $10 \%$ or 0.1 .

The results of the analysis show that the aspect of production is the most important aspect to put in priority for the development of the plantation. This finding is reasonable because plantation farmers are still faced with the low productivity. For example coffee, Amarta (2010) and Ibrahim and Zailani (2010) found that among five problems in developing plantation crops, low productivity is the main problem. In addition, many planters have low productivity in which they produced approximately $60 \%$ of potential production. In addition, the production aspect relates to the volume of production yielded which in turn will affect the amount of income received. For most farmer households living around TNKS, plantations, especially coffee, are the main source of their household income (Sukiyono et al., 2013; Windirah et al., 2014). This condition is also happen widely in which estimated 125 million people in the developing world are dependent on coffee for their livelihoods (Osorio, 2002; Lewin et al., 2004; NCA, 2017). Thus, low productivity will affect their house income.

Another reason is that their plantation crop production is still low or fluctuate or their plantation crops do not yield production according to the plant age. This is allegedly caused by the quality of planted seeds. Farmers could have difficulty in nurturing their plantation crops. Therefore, this research is not surprised to place the seed assistance program as the most important program in the production aspect. This finding is based on the AHP results showing that from 3 plantation development programs in the production aspect, the seed support program is the most important compared to two other programs, namely, providing soft loans and the expansion of access to production inputs. Figure 2 shows the plantation production development program on the aspect of production. AHP results show an inconsistency ratio of 0.03 or only $3 \%$.

The second important aspect of crop plantation development is the technological aspect. This finding considered quite important is reasonable. The disclosure of information enables farm households to gather much about technology, but the technology has probably only been seen but has not been tried or applied for. In other words, many technologies are available but not yet disseminated to farm households. The availability of natural resources and labor is quite widely available and has not been optimized, especially the resources associated with the plantation. From the survey, the availability of animal feed in plantation, for example, is 
Table 1 Decision modeling for improving household economies

\begin{tabular}{|c|c|c|}
\hline Objective & Criteria & Strategies \\
\hline \multicolumn{3}{|l|}{ Plantation crops } \\
\hline \multirow{12}{*}{$\begin{array}{l}\text { Development } \\
\text { plantation crop }\end{array}$} & \multirow{3}{*}{ Production aspect } & Increasing input accessibility \\
\hline & & Provision of soft loans. \\
\hline & & Seed assistance \\
\hline & \multirow{3}{*}{ Technology } & Introduction of estate livestock integration technology \\
\hline & & Introduction to storage technology \\
\hline & & Optimization of plant waste utilization \\
\hline & \multirow{3}{*}{$\begin{array}{l}\text { Human resources } \\
\text { develoment }\end{array}$} & Increased cultivation skills \\
\hline & & Increased product marketing knowledge \\
\hline & & Improved post-harvest skills \\
\hline & \multirow{3}{*}{ Marketing aspects } & Provision of pricing information \\
\hline & & Development of marketing institutions \\
\hline & & Improved market accessibility \\
\hline \multicolumn{3}{|l|}{ Food crop } \\
\hline \multirow{12}{*}{$\begin{array}{l}\text { Improved food } \\
\text { crop }\end{array}$} & \multirow{3}{*}{ Production aspect } & Increasing input accessibility \\
\hline & & Provision of soft loans. \\
\hline & & Seed assistance \\
\hline & \multirow{3}{*}{ Technology } & Increasing crop indexes \\
\hline & & Agricultural mechanization \\
\hline & & Optimization of plant waste utilization \\
\hline & \multirow{3}{*}{$\begin{array}{l}\text { Human resources } \\
\text { development }\end{array}$} & Increased cultivation skills \\
\hline & & Increased product marketing knowledge \\
\hline & & Improved post-harvest skills \\
\hline & \multirow{3}{*}{ Marketing aspects } & Provision of pricing information \\
\hline & & Development of marketing institutions \\
\hline & & Improved market accessibility \\
\hline \multicolumn{3}{|c|}{ Optimizing house yard (pekarangan) resources } \\
\hline \multirow{6}{*}{$\begin{array}{l}\text { Selecting } \\
\text { livestock }\end{array}$} & Labor number & Cattle, goats, chickens, and ducks \\
\hline & Capital requirement & Cattle, goats, chickens, and ducks \\
\hline & Income generated & Cattle, goats, chickens, and ducks \\
\hline & Waiting period & Cattle, goats, chickens, and ducks \\
\hline & Livestock raising & Cattle, goats, chickens, and ducks \\
\hline & Marketing & Cattle, goats, chickens, and ducks \\
\hline \multirow{10}{*}{$\begin{array}{l}\text { Selected livestock } \\
\text { development }\end{array}$} & \multirow{3}{*}{ Production aspect } & Livestock feed accessibility \\
\hline & & Provision of soft loans. \\
\hline & & Livestock breeding assistance \\
\hline & \multirow{2}{*}{ Technology } & Development alternative livestock feed \\
\hline & & Optimization of animal waste utilization \\
\hline & \multirow{2}{*}{$\begin{array}{l}\text { Human resources } \\
\text { development }\end{array}$} & Increased breeding skills \\
\hline & & Increased product marketing knowledge \\
\hline & \multirow{3}{*}{ Marketing aspects } & Provision of pricing information \\
\hline & & Development of marketing institutions \\
\hline & & Improved market accessibility \\
\hline
\end{tabular}




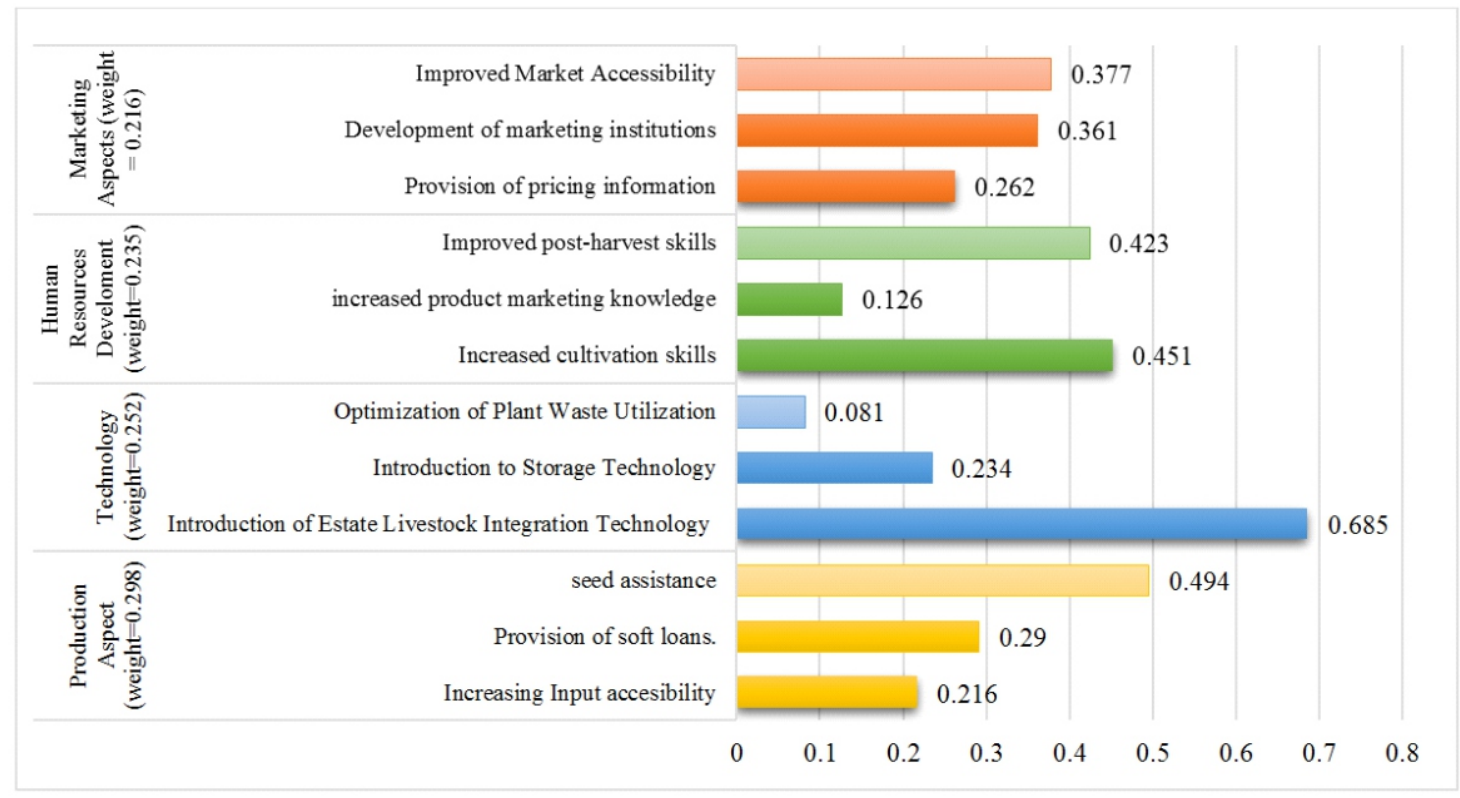

Figure 2 Priority program in plantation crop improvement.

also not yet optimized. Among the technologies that are quite interesting is the integration of livestock and estates. Many studies have found the great benefit to be gained from integrating livestock - plants, especially horticulture crops (Germani et al., 2015; Tarawali et al., 2004). As one of the most promising solutions to soil fertility decline and productivity losses in intensifying systems in Nigeria, integrated crop-livestock is frequently advocated. In mixed crop-livestock systems, crop residues are a major component of livestock diets and it is therefore important to improve the use and nutritional quality of crop residues to increase farm productivity and profitability. Therefore, the results of the AHP analysis show that priority technology alternatives concerning the development of crop plantation are presented in Figure 2.

The result of the AHP analysis shows that the marketing aspect is not a priority scale for plantation crop development. One important reason is those plantation products have a clear and steady marketing chain. Farmers can easily market their plantation crops. However, farmers are often confronted with the lack of choice of agricultural product marketing agencies in their villages or around their villages. Farmers are frequently tied to village level traders. Therefore, the priority of increasing market and marketing institutions access is an important priority in the development aspect of the marketing of plantation products, as shown in Figure 1. This is intended to reduce the oligopsony or monopoly market in the research area. Nevertheless, the alleged monopolistic or oligopsony practices need more detailed studies.

Improved food crops Apart from plantation crops, food crops are also cultivated by farmer households around TNKS. Therefore, the existence of this plant is very important for the household economy. This food crop production failure also affects household welfare because this plant contributes approximately $30 \%$ of total household income (Sukiyono et al., 2013; Windirah et al., 2014). Therefore, efforts to develop and increase the role and function of this crops are wise to conducts.

Using the similar approach, i.e., AHP method, the priority aspects of food crops development can be found quantitatively, as follows (Figure 3): (a) technology (0.257); (b) human resources $(0.325)$; (c) marketing $(0.183)$; and (d) production (0.236). These results inform that the human resources aspect is a priority food crop improvement. This aspect emphasizes the importance of improving the knowledge and skills quality of farmers. The low level of farmer education and the irregularity of agricultural extension services are alleged to be a trigger for farmers to choose the human resource improvement aspects as a priority in the improvement of food crops. As Manikandan and Abdullah (2016) stated, the most important resources that relies on the use of science and technology for advancement is human resources. As the backbone of the countries' economy, agriculture requires human resources to fulfill various agricultural development-related activities that are critical to achieving the country's rural development goals, generating jobs, and hosting related activities leading to sustainable growth and development. AHP also results that the second important aspect is the technological aspect. The technological aspect still seems to be an important aspect to be implemented to increase food crops as farmers are still oriented towards increasing the production of their food crops. In line with this finding, FAO (2012), Bauckhage et al. (2012) concluded that to produce enough food at an acceptable cost relies heavily on intensive research on everything from new seed varieties to more efficient cultivation techniques. The high production resulting from the implementation of new technology will be able to increase the income and welfare of food crop farmers, especially paddy farmers. The importance of technology was 


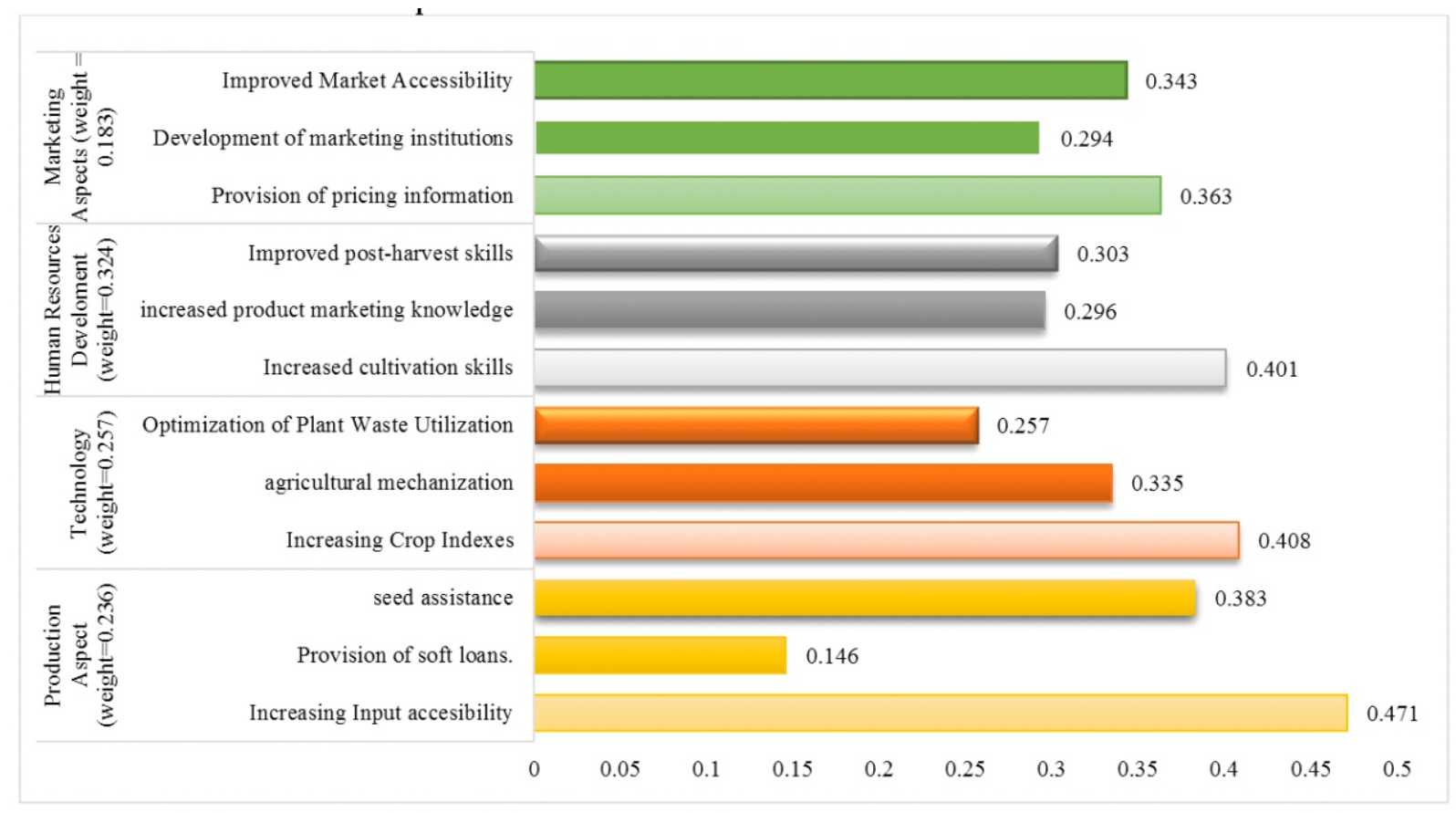

Figure 3 Priority program in food crop improvement.

also mentioned by Jain et al. (2019) in which new agricultural technologies that improve sustainable food production are therefore vital to sustainable food security and economic growth. This has made the complexities of technological transition in agriculture an area of extensive study since the early twentieth century.

Technological aspects are followed by the production aspect to be an important aspect to be implemented. Increasing food crop production is still the main concern of most farmers, and this is reasonable because increased production will have an impact on improving the welfare of farm households. That is why aspects of production and technology occupy the most important sequence in improving food crops after human resources aspects. The low level of productivity also causes the importance of these three aspects to be a development priority. Meanwhile, aspects of marketing appear to be less important aspects to be done in increasing production. One of the arguments is that many paddy farmers in the research area still have a crop index of 100 , meaning that they only cultivate paddy once a year. With low productivity, production produced tends only to fulfill their household needs (subsistence).

Further analysis using AHP also results in improving skills for the cultivation of food crops as a priority program (Figure 3). This cultivation skill is related to pest problems of rats that farmers often face. Due to this pest, farmers only have less than 100 cropping indexes while they do not face problems of irrigation water availability. The improvement of product marketing knowledge does not become the priority choice program or the last option with a weight of 0.296. This result is consistent with findings that the marketing aspect is unimportant as discussed above. Furthermore, of the three options in production aspects, an increase in cropping index $(\mathrm{CI})$ is a top priority with a weight of 0.408 followed by mechanization of agriculture (weight $=$ 0.335 ) and optimization of plant waste utilization (weight $=$ 0.257 ). Increased CI also appears to be a priority scale in addition to increasing production and income, as well as optimizing paddy farm resources owned by farmers. As described above, the main problem in increasing $\mathrm{CI}$ is rat pest. Therefore, technological and social engineering must be done to solve this problem. The mechanization of agriculture needs to be introduced to increase CI as well. By mechanization, the labor savings and acceleration of the cultivation process can be done.

The low productivity of food crops can also be caused by the difficulty of farmers accessing input production and the use of other production inputs. Many studies have concluded that the problem of access to farming inputs increasingly difficult to cause a decline in motivation of farmers in managing their farming (Simanjuntak et al., 2019). Therefore, increasing access to input production is an absolute necessity to increase the production of food crops. This conclusion is also reflected in the priority programs on production aspects, whereas the following sequence of priority programs of AHP results are as follows: (a) seed Assistance (weight $=0.383$ ), (b) provision of soft loans (weight $=0.146$ ), and (c) accessibility of fertilizer and marketing (weight $=0.471$ ) with inconsistency ratio $=$ 0.0018 .

Optimizing house yard (pekarangan) resources A survey by Sukiyono et al. (2013) recognizes two potential households' resources, namely, House yard (called pekarangan) with an average of $1,302.57 \mathrm{~m}^{2}$ and household labor. They also note that this pekarangan has not been optimally utilized economically by 97 percent of households. This finding is consistent with the report of Mardiharini (2011). Mardiharini (2011) reported that the 
utilization of farmers' yards is still very limited. In fact, the yard can be utilized for the development of livestock, fish and other agricultural crops. As a result, the technology for utilizing the yard has not been developed optimally. Another resource is the availability of households' labor and most of them are in productive age and not utilized optimally. The survey also shows that the number of household members was relatively small, i.e., between 2-4 persons.

Departing from these resources, FGD results that optimizing the yard is based on livestock development. The development of the livestock sub-sector plays an important role in improving the quality of human resources through improving nutrition, increasing income, improving the welfare and providing job opportunities for the community. AHP model for livestock development at households' scale is presented in Figure 4. This decision-making hierarchy consists of two steps in this decision-making, the selection of livestock to be developed, and the determination of aspects and development programs. The first stage, the selection of livestock, given 4 (four) alternative types of livestock, namely cattle, goats, chickens, and ducks. The selection is based on six criteria, namely: (a) the number of labor, (b) capital requirement, (c) income generated, (d) waiting period, (e) livestock raising, and (f) marketing.

The results of AHP data analysis show that of these six criteria and with an inconsistency ratio of 0.02 ; the capital needs factor becomes the main consideration when choosing the type of livestock to be raised (weight $=0.274$ ). This finding is reasonable because capital will and often restrict farmers in investing to diversify their household incomes (Ntshangase et al., 2018). Any type of livestock raised will require different investments or capital. The second criterion chosen is the market aspect. The market is the estuary of agricultural production. All investments made by farmers must yield marketable and valuable products. Thus, investments made can be profitable, or at least, not detrimental to farmers. Although farmers have sufficient capital to invest and market their products available, farmers will find it difficult to adopt livestock as an income diversification effort if they lack the technical skills and knowledge of raising livestock. This argument is supported by the AHP results indicating that livestock raising is the third criterion to consider when selecting livestock. The livestock raising aspect weights 0.183 while the marketing has a higher weight of 0.205 . Table 2 presents the results of the AHP selection of livestock species based on the criteria described above.

Table 2 shows that chicken becomes the main choice based on three criteria, namely, harvesting waiting period, livestock raising, and marketing. Each of these criteria weights $0.359,0.390$, and 0.390 , respectively. This is understandable because the chicken takes a short time to harvest compared to 3 other livestock. Similarly, chicken is the easiest livestock to raise and market compared to other

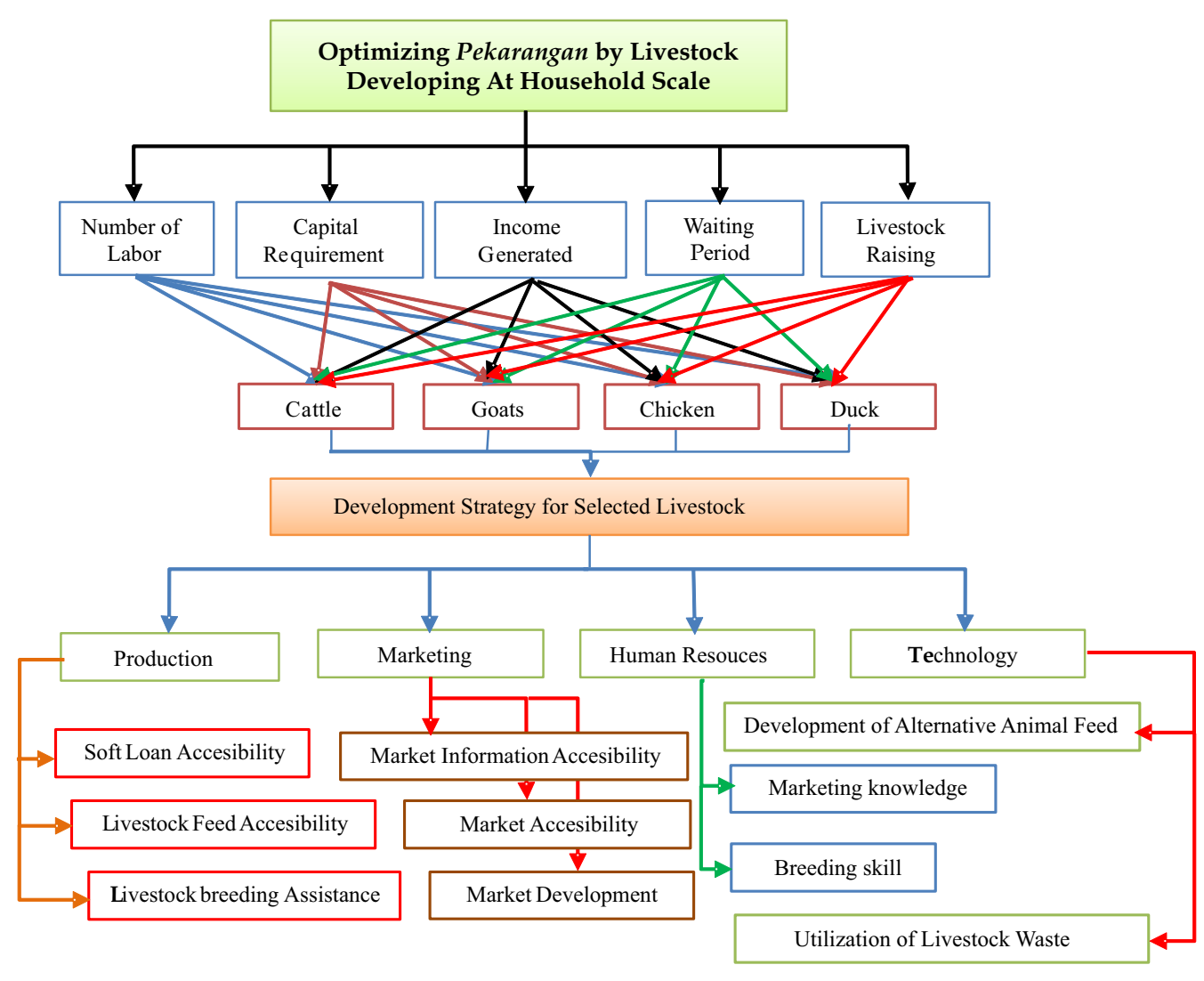

Figure 4 AHP model for optimizing pekarangan by livestock development. 
alternative livestock.

From the income criteria, farmers choose the cow as the main choice. This choice is reasonable because the cow will provide the highest income compared to the other three cattle. The results of the AHP analysis also show this finding that the cow has the highest weight, that is, 0.299. This weight is followed by chickens, goats, and ducks with a weight of $0.267,0.257$, and 0.177 , respectively. AHP results also show that raising cattle requires a substantial capital cost (weight $=0.291$ ). Chicken is considered a capital-intensive livestock business as well (weight $=0,277$ ). Furthermore, ducks require the highest labor force compared to other alternatives (weight $=0.267$ ). This finding is reasonable because raising ducks must be brought to the fields or raised intensively compared to chickens, goats, or cows.

If all the criteria are combined and used to select priority livestock species, the AHP result concludes that chicken is the primary choice (Table 1). The chicken weights of 0.325 . The results of the AHP are not surprising. When analyzed individually, chickens have advantages over the three criteria used as discussed above. Meanwhile, cattle rank second because it has an advantage income. AHP results also show that ducks are the last alternative. These animals only excel in relatively small capital requirements compared to others but require enough labor-intensive.

After selecting livestock types, the next process is to determine aspects of development. This analysis also uses AHP as described above. There are 4 aspects as considerations, namely, production, marketing, human resources, and technology. The AHP result to determine the priority criterion is presented in Figure 5.

Aspects of production is also a priority strategy for chicken development. This conclusion is based on AHP results where this aspect has the highest weight, that is, 0.329 . The production aspect in chicken development consists of chicken breeding (day old chicken, DOC) support, provision of soft credit, and increased feed accessibility. Among these 3 alternative programs, DOC assistance is a program desired by farm households, followed by increasing feed accessibility and provision of soft credits. Each of these programs weights $0.512,0.246$, and 0.242 , respectively with a 0.02 inconsistency ratio as shown in Figure 5 .

Although development programs in the form of DOC support are rarely implemented by the regional government, this program seems to be worth trying to conduct. This is important because with the help of domestic seedlings farmers can immediately start their business to diversify income. The development of chicken livestock should be supported by the ease of poultry feed accessibility and the provision of soft loans. These programs will accelerate the increase of farmers' incomes which in turn will reduce household dependence on forests and non-forest products.

In the marketing aspect, the results of the analysis using AHP indicate that the proposed programs for the development of livestock are: (a) provision of price information (weight $=0.221$ ), (b) market accessibility (weight $=0.382$ ), and $(\mathrm{c})$ livestock market development (weight $=0.398)$ with an inconsistency ratio of 0.0016 . These results inform that the the expansion of livestock market is an important effort to facilitate the marketing of chicken livestock being developed. This program is important as more and more households participate. The development of this livestock market can be done locally as well as regionally. For this reason, market development must be accompanied by the expansion of market access for farmers. Furthermore, the development of human resources, especially breeders, should be a concern in the development of chickens. Many farmers have business and experience in raising chickens, but most of their businesses are not on an economic scale. The function of raising chickens for them only as a reserve of food supplies or meet the needs of protein for their family. The development of human resources is mainly done by increasing the capability of farmers in raising livestock. This program has a weight of 0.833 which is followed by the improvement of marketing knowledge with a weight of 0.167 (Figure 5).

According to these analyses, optimizing economic resources in the villages around the conservation forest (TNKS) needs some strategies with the concern of increasing the villagers' income-generating activities. There are three major strategy namely developments plantation crops, improved food crops, and optimizing house yard for livestock development at households' scale, especially chicken. These strategies should be derived into some programs that follow. Many programs should be proposed to increase the yield of these products. But these analyses suggest to bring us into programs priority. Table 3 below summarizes the need for the consecutive program's priority.

Regarding the efforts to increase household income who live around the forest, some aspects that respect the sustainability of the environment should be considered. However, these two attempts cannot be put in opposite positions. The growth of households' economic can parallel with the carrying capacity of the environment. Thus, it is

Table 2 Choice of livestock species based on each criterion

\begin{tabular}{llccccccc}
\hline No & Livestock & $\begin{array}{c}\text { Labor } \\
\text { need }\end{array}$ & $\begin{array}{c}\text { Capital } \\
\text { need }\end{array}$ & $\begin{array}{c}\text { Income } \\
\text { generated }\end{array}$ & $\begin{array}{c}\text { Harvesting } \\
\text { waiting period }\end{array}$ & $\begin{array}{c}\text { Livestock } \\
\text { raising }\end{array}$ & Marketing & $\begin{array}{c}\text { All } \\
\text { criteria }\end{array}$ \\
\hline 1 & Cattle & 0.237 & $\mathbf{0 . 2 9 1}$ & $\mathbf{0 . 2 9 9}$ & 0.186 & 0.153 & 0.234 & 0.242 \\
2 & Goat & 0.259 & 0.227 & 0.257 & 0.213 & 0.202 & 0.185 & 0.219 \\
3 & Duck & $\mathbf{0 . 2 6 7}$ & 0.205 & 0.177 & 0.242 & 0.255 & 0.190 & 0.214 \\
$4 \quad$ Chicken & 0.237 & 0.277 & 0.267 & $\mathbf{0 . 3 5 9}$ & $\mathbf{0 . 3 9 0}$ & $\mathbf{0 . 3 9 1}$ & $\mathbf{0 . 3 2 5}$ \\
\hline $\begin{array}{l}\text { Inconsistency } \\
\text { ratio }\end{array}$ & 0.004 & 0.020 & 0.050 & 0.011 & 0.022 & 0.050 & 0.012 \\
\hline
\end{tabular}


expected that the consecutive program's priority will be run well, then the increase of the household income can improve their wellbeing. Therefore forest encroachment activities will be decreasing.

Enhancing food crops by increasing its production is a challenge in terms of agricultural development. Due to high yield may be increasing farmer smallholders in their household income. Farmers still maintain their survival level on their food production by itself. Even though depending based on subsistence, farmers can be more vulnerable. The main indicator can be seen by the rate of forest encroachment. We can conclude that although farmers still subsistence, as whole farmers in developing countries, they need to be commercializing their crops product. In this respect, Hailua et al. (2015) proposed that farmers' participation in crop commercialization has a positive and significant impact on smallholder livelihoods through improved income and asset holdings. Their research indicated that participation in crop commercialization has a positive, robust, and statistically significant effect on income and livestock holding. Therefore, crop commercialization has a positive and significant effect on improving rural farmers' livelihoods.

This is not a problem for plantation products because these products belong to commercial products. One problem is how to increase the quality of the products sold by farmers. The program's concern with increasing plantation production addressed farmer's capability in producing commodities that competitive quality. The plantation commodities businesses by local farmers, i.e rubber, coffee, and palm, usually take low prices because of its.

Good product quality will make it easier for farmers to be involved in the market of plantation products. Of course, facilitation and assistance from the regional government are needed. While the increase in plantation products, which are the main business of farmers, is intended as a step to improve welfare, side businesses such as empowering chicken farms

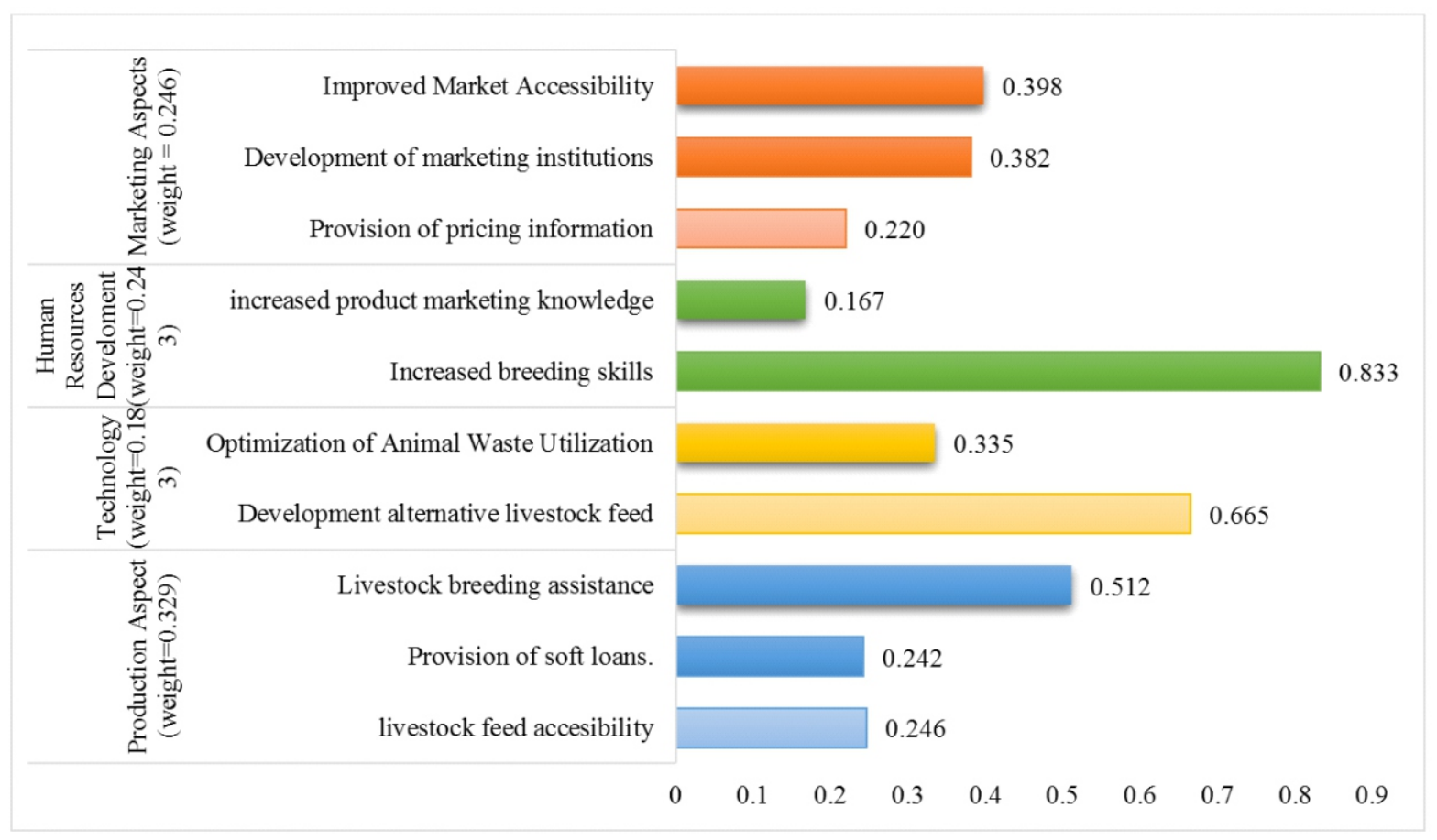

Figure 5 Chicken development priority program.

Table 3 The strategy for optimizing resources and the priority of the program

\begin{tabular}{ll}
\hline \multicolumn{1}{c}{ The strategy for optimizing resources } & \multicolumn{1}{c}{ The program's priority } \\
\hline Developments plantation crops & $\begin{array}{l}\text { Seed support program, the introduction of estate livestock technology, } \\
\text { increased cultivation skills, improved market accessibility }\end{array}$ \\
Improved food crops & $\begin{array}{l}\text { Increasing inputs accessibility, increasing crop indexes, increased } \\
\text { cultivation skill, provision of price information }\end{array}$ \\
$\begin{array}{l}\text { Optimizing House Yard (livestock } \\
\text { development at households' scale } \\
\text { especially chicken) }\end{array}$ & $\begin{array}{l}\text { Livestock breeding assistance, development alternatives feed, increased } \\
\text { breeding skills, improved market accessibility }\end{array}$ \\
\hline
\end{tabular}


in the yard become a buffer when facing a crisis. The coconut plantations cultivated by farmers have the main function as staple food needed by the village community in the research location.

Commercialization of agricultural products is characterized by the increased involvement of farmers in exchanges in the product market (Hailua et al., 2015) and the development of agricultural commodity-based side businesses, which in turn can generate household income security. Livelihood security is the outcome of all livelihood diversification activities which today is still a problem for low-income households in rural areas (Bhandari \& Grant, 2007). Furthermore, livelihood security is a way to reduce vulnerability for villagers in the long run (Ekblom, 2012). Achieving long-term livelihood security and decreasing vulnerability are the paths that should be realized so, therefore, the population pressures on the forests become lower.

\section{Conclusion}

This study reveals that several important aspects should be taken into consideration in policy design for optimizing households' economic resources. For improving plantation crops, the production aspect is the most important. Of the 3 identified programs, households place seed assistance as the most important program compared to a soft loan provision and an expansion of accessibility to production inputs. Meanwhile, a human resource development aspect is a priority aspect of food crop development. This aspect of human resource development focuses more on improving farmers' knowledge in cultivating compared to marketing and post-harvest handling. The optimization of pekarangan resources is directed to the development of chicken farms where the development is focused on improving the production aspect. Three priority consecutive programs are DOC assistance, access to soft credits, and livestock feed.

\section{Acknowledgment}

This research was fully funded by the Ministry of Research, Technology and Higher Education, the Republic of Indonesia. Therefore, we would like to thank all those who have contributed to the implementation of this research.

\section{References}

Al-Harbi, K. (2001). Application of the AHP in project management. International Journal of Project Management, 19, 19-27. https://doi.org/10.1016/S02637863(99)00038-1

Amarta. (2010, December 28). Value chain interventions for developing North Sumatra arabica coffee competitiveness [Paper presentation]. Workshop of Regional Agribusiness Competitiveness for Agricultural Value Chains. Simalungun District, North Sumatera.

Bhandari, B. S., \& Grant, M. (2007). Analysis of livelihood security: A case study in the Kali-Khola watershed of Nepal. Journal of Environmental Management, 85, 17-26. https://doi.org/10.1016/j.jenvman.2006.07.010
Barrett, C., Reardon, T., \& Webb, P. (2001). Nonfarm income diversification and household livelihood strategies in rural Africa: Concepts, issues, and policy implications. Food Policy, 26(4), 315-331. https://doi.org/10.1016/ S0306-9192(01)00014-8

Bauckhage, C., Kersting, K., \& Schmidt, A. (2012). Agriculture's technological makeover. IEEE Pervasive Computing, 11(2), 4-7. https://doi.org/10.1109/MPRV. 2012.25

Block, S., \& Webb, P. (2001). The dynamics of livelihood diversification in post-famine Ethiopia. Food Policy, 26(4), 333-350. https://doi.org/10.1016/S03069192(01) 00015-X

Brunelli, M. (2015). Introduction to the analytic hierarchy process. New York: Springer.

Bryceson, D. F., \& Jamal, V. (1997). Farewell to farms: Deagrarianisation and employment in Africa. Aldershot: Ashgate.

Byun, Dae-Ho. (2001). The AHP approach for selecting an automobile purchase model. Information \& Management, 38, 289-297. https://doi.org/10.1016/ S0378-7206(00)00071-9

Canagarajah, S., Newman, C., \& Bhattamishra, R. (2001). Non-farm income, gender, and inequality: Evidence from rural Ghana and Uganda. Food Policy, 26(4), 405-420. https://doi.org/10.1016/S0306-9192 (01)00011-2

Chang, C., Wu, C., Lin, C., \& Chen, H. (2007). Application of AHP and sensitivity analysis for selecting the best slicing machine. Computer and Industrial Engineering, 53(2), 296-307. https://doi.org/10.1016/j.cie.2006. 11.006

Démurger, S., Fournier, M., \& Yang, W. (2010). Rural households' decisions towards income diversification: Evidence from a township in Northern China. China Economic Review, 21, S32-S44. Retrieved from https://halshs.archives-ouvertes.fr/halshs-00550457

Dubey, B. (2012). Modeling effects of two interacting populations on a renewable resource. Natural Resource Modelling, 25(2), 325-363. https://doi.org/10.1111/ j.1939-7445.2011.00109.x

Dubey, B., \& Narayanan, A. S. (2010). Modelling effects of industrialization, population and pollution on a renewable resource. Nonlinear Analysis Real World Applications, 11(4), 2833-2848. https://doi.org/10.1016/ j.nonrwa.2009.10.007

Dubey, B., Sharma, S., Sinha, P., \& Shukla, J. B. (2009). Modelling the depletion of forestry resources by population and population pressure augmented industrialization. Applied Mathematical Modelling, 33, 
3002-3014.https://doi.org/10.1016/j.apm.2008.10.028

Ekblom, A. (2012). Livelihood security, vulnerability, and resilience: A historical analysis of Chibuene, Southern Mozambique. AMBIO, 41, 479-489. https://doi.org/10. 1007/s13280-012-0286-1

[FAO] Food and Agriculture Organization. (2012). FAO says food production must rise by 70 . Retrieved from http://www.populationinstitute.org/resources/populatio nonline/issue/1/8/

Gnanasekaran, S., Selladurai, V., \& Manimaran, P. (2006). Application of analytical hierarchy process in supplier selection: An automobile industry case study. South Asian Journal of Management, 13(4), 89-98.

Germani, C., Rodolpho F. M., Sabrina A. S., Ignor V.T. C., Waggner, G. P., Maxwell, S. V., ..., \& Larissa T. L. (2015). Integrated crop-livestock: Is it efficient in suppressing troublesome weeds? A case study. African Journal of Agricultural Research, 10, 1882-1890. https://doi.org/10.5897/AJAR2015.9528

Guvele, C. A. (2001). Gains from crop diversification in the Sudan Gezira scheme. Agricultural Systems, 70, 319-333. https://doi.org/10.1016/S0308-521X(01) 00030-0

Hailua, G., Manjureb, K., \& Kiros, M. A. (2015). Crop commercialization and smallholder farmers' livelihood in Tigray Region, Ethiopia. Journal of Development and Agricultural Economics, 7(9), 314-322. https://doi.org/ 10.5897/JDAE2015.0649

Huang, J., Wu, Y., \& Rozelle, S. (2009). Moving off the farm and intensifying agricultural production in Shandong: A case study of rural labor market linkages in China. Agricultural Economics, 40(2), 203-218. https://doi.org/ 10.1111/j.1574-0862.2009.00370.x

Ibrahim, H. W., \& Zailani, S. (2010). Review on the competitiveness of global supply chain in a coffee industry in Indonesia. International Business Management, 4(3), 105-115. Retrieved from https://eiado.aciar.gov.au/sites/default/files/IbrahiZailani(2010)ReviewCompetitivenessGlobalSupplyCh ain CoffeeIndustryIndo_UniSainsMalaysia.pdf

Jain, C., Khatana, S., \& Vijayvergia, R. (2019). Bioactivity of secondary metabolities of various plants: A review. International Journal of Pharmaceutical Sciences and Research, 10, 494. https://doi.org/10.13040/IJPSR. 0975-8232.10(2).494-04

Lewin, B., Giovannucci, D., \& Varangis, P. (2004). Coffee market: New paradigms in global supply and demand. Agriculture and Rural Development Discussion Paper 3. Washington DC: World Bank, Agriculture and Rural Development Department.
Little, P. D., Smith, K., Cellarius, B. A., Coppock, D. L., \& Barrett, C. B. (2001). Avoiding disaster: Diversification and risk management among East African herders. Development and Change, 32, 401-433. https://doi.org/ 10.1111/1467-7660.00211

Losch, B., Freguingresh, S., \& White, E. (2011). Rural transformation and late developing countries in a globalizing world: A comparative analysis of rural change. Final report of the RuralStruc program (Revised version). Washington DC: World Bank.

Mardiharini, M. (2011). Model kawasan rumah pangan lestari dan pengembangannya ke seluruh provinsi di Indonesia. Warta Penelitian dan Pengembangan Pertanian, 33(6), 35. Retrieved from http://203.190.37. 42/publikasi/wr336111.pdf

Misra, A. K., Lata, K. \& Shukla, J. B. (2014). Effects of population and population pressure on forest resources and their conservation: A modeling study. Environment, Development and Sustainability, 16, 361-374. https://doi.org/10.1007/s10668-013-9481-X

Manikandan, M., \& Abdullah, S. (2016). Human resource development for agricultural sector in India. International Journal of Environment, Agriculture and Biotechnology, 1, 723-728. https://doi.org/10.22161/ ijeab/1.4.15

[NCA] National Coffee Association. (2017). Coffee around the world. Retrieved from http://www.ncausa.org/ About-Coffee/Coffee-Around-the-World.

Ntshangase, N. L., Muroyiwa, B., \& Sibanda, M. (2018). Farmers' perceptions and factors influencing the adoption of no-till conservation agriculture by small-scale farmers in Zashuke, KwaZulu-Natal Province. Sustainability, 10, 555. https://doi.org/10.3390/su10020555

Osorio, N. (2002). The global coffee crisis: A threat to sustainable development. London: International Coffee Organization.

Rachman, H. P. S., Purwantini, T. B., \& Marisa, Y. (2006). Prospek diversifikasi usaha rumah tangga dalam mendukung ketahanan pangan dan penanggulangan kemiskinan. Forum Penelitian Agro Ekonomi, 24(1), 11-13.

Rambe, L. (2012). Perambahan hutan, musuh ttama Taman Nasional Kerinci Sebelat. Retrieved from https:/www.mongabay.co.id/2012/10/04/perambahanhutan-musuh-utama-taman-nasional-kerinci-sebelat/

Reardon, T. (1997). Using evidence of household income diversification to inform the study of the rural nonfarm labor market in Africa. World Development, 25(5), $735-748$.

Reardon, T., Taylor, J., Stamoulis, K., Lanjouw, P., \& 
Balisacan, A. (2000). Effects of nonfarm employment on rural income inequality in developing countries: An investment perspective. Journal of Agricultural Economics, 51(2), 266-288. https://doi.org/10.1111/ j.1477-9552.2000.tb01228.x

Saaty, T. L. (1980). The analytic hierarchy process. New York: McGraw-Hill.

Saaty, T. L. (2008). Decision making with the analytic hierarchy process. International Journal of Services Sciences, 1(1), 83-98. https://doi.org/10.1504/IJSSCI. 2008.017590

Saaty, T. L. (2012). Decision making for leaders: The analytic hierarchy process for decisions in a complex world (3rd ed.). Pittsburgh: RWS Publications.

Senoaji, G, \& Ridwan, M. (2006). Studi identifikasi tekanan penduduk ke dalam hutan di daerah interaksi hutan lindung Bukit Daun Kabupaten Kepahiang Propinsi Bengkulu. Laporan Penelitian Dosen Muda. Jakarta: Dirjen DIKTI.

Shahroodi, K., Keramatpanah, A., Amini, S., Shiri, E., \& Najibzadeh, M. (2012). Application of analytical hierarchy process (AHP) technique to evaluate and selecting suppliers in an effective supply chain. Arabian Journal of Business and Management Review, 1(6), 119-132. Retrieved from https://www.arabianjbmr. com/pdfs/KD_VOL_1_6/9.pdf

Simanjuntak, B., Sukiyono, K., \& Sriyoto. (2019). Analisis fungsi produksi dan efisiensi alokatif usahatani ubi jalar di Kecamatan Hulu Palik Kabupaten Bengkulu Utara. AGRISEP, 18(1), 187-202. https://doi.org/10.31186/ jagrisep.18.1.187-202

Simon, H. (2000). Hutan jati dan kemakmuran. Problematika dan strategi pemecahan. Yogyakarta: BIGRAF Publishing.

Subarna, T. (2011). Faktor yang mempengaruhi masyarakat menggarap lahan di hutan lindung: Studi kasus di Kabupaten Garut Jawa Barat. JURNAL Penelitian Sosial dan Ekonomi Kehutanan, 8(4), 265-275. https://doi.org/ 10.20886/jpsek.2011.8.4.\%p

Sukiyono, K. (2018). Penelitian survai dan teknik sampling. Bengkulu: BPFP Universitas Bengkulu

Sukiyono, K., Widiono, S., \& Apriyanto, E. (2013). Diversifikasi ekonomi rumah tangga pada desa-desa sekitar Taman Nasional Kerinci Seblat di Kabupaten Lebong Provinsi Bengkulu. AGRISEP, 12(1), 31-40. https://doi.org/10.31186/agrisep.12.1.31-40

Sukiyono, K., Widiono, S., \& Apriyanto, E. (2014, August 19-21). Aksesibilitas masyarakat ke hutan dan faktorfaktor yang mempengaruhinya: Kasus pada rumah tangga di desa-desa sekitar TNKS Kabupaten Lebong [Paper presentation]. Seminar Nasional dan Rapat
Tahunan BKS-PTN Wilayah Barat Ilmu Pertanian Tahun 2014: Penguatan Pembangunan Pertanian Berkelanjutan untuk Mencapai Kemandirian Pangan dan Mengembangkan Energi Berbasis Pertanian, Fakultas Pertanian Universitas Lampung, Lampung.

Sukiyono, K., Widiono, S., \& Apriyanto, E. (2015, August 20-21). Diversifikasi pendapatan dan tingkat kesejahteraan rumah tangga: Kajian pada rumah tangga di desa-desa sekitar Taman Nasional Kerinci Seblat (TNKS) Kabupaten Lebong Provinsi Bengkulu. [Paper presentation]. Seminar Nasional dan Rapat Tahunan BKS-PTN Wilayah Barat Ilmu Pertanain Tahun 2015: Pembangunan Pertanian Berkelanjutan Berbasis Kedaulatan Pangan dan Energi untuk Meningkatan Perekonomian Nasional, Fakultas Pertanian Universitas Palangkaraya, Palangkaraya.

Tarawali, S. A., Keatinge, J. D. H., Powell, J. M., Hiernaux, P., Lyasse, O., \& Sanginga, N. (2004). Integrated natural resource management in West African crop-livestock systems. In T. O. Williams, S. A. Tarawali, P. Hiernaux, S. Fernandez-Rivera (Eds.), Sustainable Crop-livestock Production for Improved Livelihoods and Natural Resource Management in West Africa (pp. 8089). Ibadan: IITA.

Timor, M., \& Tuzuner, L. (2006). Sales representative selection of pharmaceutical firms by analytical hierarchy process. Journal of American Academy of Business, 8(1), 287-293.

[WALHI] Wahana Lingkungan Hidup Bengkulu. (2008). Kerusakan hutan Taman Nasional Kerinci Sebelat Wilayah Kabupaten Lebong, Propinsi Bengkulu. Retrieved from http://cfors.wordpress.com/ 2008/03/14/kerusakan-hutan-tamannasional-kerincisebelat-wilayah-kabupaten-lebong-propinsibengkulu.

Wan, J., Li, R., Wang, W., Liu, Z., \& Chen, B. (2016). Income diversification: A strategy for rural Region risk management. Sustainability, 8, 1-12. https://doi.org/ $10.3390 /$ su8101064

Weinberger, K., \& Lumpkin, T. A. (2007). Diversification into horticulture and poverty reduction: A research agenda. World Development, 35(8), 1464-1480.

Widiono, S., Sukiyono, K., \& Apriyanto, E. (2013, September, 17-18). Population pressure on the villages around Kerinci Seblat National Park (TNKS) District of Lebong, Province of Bengkulu, Indonesia [Paper presentation]. The 3rd International Symposium for Sustainable Humanosphere (ISSH) a Forum of Humanosphere Science School (HSS), Bengkulu.

Windirah, N., Sukiyono, K., \& Widiono, S. (2014). Faktorfaktor yang mempengaruhi diversifikasi pendapatan rumah tangga di desa-desa sekitar kawasan Taman Nasional Kerinci Seblat (TNKS) Kabupaten Lebong Provinsi Bengkulu. AGRISEP, 13(2), 177-186. 
https://doi.org/10.31186/agrisep.13.2.177-186

Wollenberg, E., Belcher, B., Sheil, D., Dewi, S., \& Moeliono, M. (2004), Mengapa kawasan hutan penting bagi penanggulangan kemiskinan di Indonesia? CIFOR, Governance Brief No. 4(i), December 2004. Retrieved from http://www.cifor.org/publications/pdf_files/ govbrief/GovBrief0404I.pdf 